\title{
PARTICIPAÇÃO DAS DEPRESSÕES PERIFÉRICAS E SUPERFÍCIES APLAINADAS NA COMPARTIMENTAÇÃO DO PLANALTO BRASILEIRO - CONSIDERAÇÕES FINAIS E CONCLUSÕES
}

\author{
Aziz Nacib AB' SÁBER
}

Aos poucos, vai se evidenciando que, para o estudo paleogeográfico dos diversos lapsos de tempo geológico que respondem pela gênese e evolução das terras brasileiras, torna-se imprescindível a aplicação de métodos específicos de trabalho, utilizados segundo um rumo e uma combinação de técnicas inteiramente distintas para cada um dos casos que se tenha em vista. Pode-se afirmar que, para a seqüência pré-devoniana, o campo de estudos pertence inteiramente aos petrólogos, geoquímicos, estratígrafos especializados em tectônica plástica de orogenias antigas, assim como a especialistas de laboratórios de cronogeologia. No que concerne às grandes seqüências e pacotes de sedimentos empilhados nas diversas bacias intracratônicas brasileiras, têm a palavra os estratígrafos, os paleontólogos e os sedimentologistas, especializados em estudos de microestruturas e paleoecologia. Mesmo porque seria impossível realizar qualquer coisa de mais positivo - geologicamente falando sem a utilização combinada de tais ciências da Terra, da Água e da Vida, no que diz respeito à abordagem dos depósitos sedimentares que se formaram do Devoniano até o Cretáceo nas diferente bacias paleomesozóicas brasileiras. Por último, no que tange precipuamente aos diferentes domínios de sedimentos pós-cretácicos, par a par com todos esses métodos clássicos de trabalho geológico, há que acrescentar a contribuição dos geomorfologistas e pedólogos, assim como a dos sedimentologistas dotados de uma sensibilidade especial por assuntos paleoclimáticos. Estamos certos de que qualquer ortodoxia, nesse último setor de estudos - pelo menos no que diz respeito ao caso brasileiro e aos de muitos outros territórios gondwânicos -, seria extremamente negativa para obtenção de resultados científicos de mais alcance, assim como, sobretudo, para a feitura de uma verdadeira Paleogeografia integrada e sem fronteiras.
Queremos crer que, no plano internacional, até o presente momento da história das ciências da Terra, tenha sido para com o estudo do Quaternário que os critérios morfológicos foram ensaiados com resultados mais concretos e até certo ponto de vista inesperados. Estamos cientes, por outro lado, de que, pelo menos em relação ao caso do território brasileiro, teremos que forçar a extensão de tais métodos para os períodos pré-quaternários; procedimento esse que certamente comportará uma margem de erros incomparavelmente maior, como, aliás, sempre acontece cada vez que nos ocupamos com lapsos de tempo geologicamente mais antigos. Evidentemente, o presente estudo persegue tais objetivos, podendo ser considerado uma tentativa de aplicação de métodos cronogeomorfológi$\cos$ ao estudo da compartimentação interior do Planalto Brasileiro, área territorial que possui uma escala e uma ordem de grandeza de amplitude subcontinental. Estuda-se, de preferência, por essa razão mesma, a macrocompartimentação topográfica dessa grande área de escudos, núcleos-de-escudo e bacias intracratônicas. Estamos absolutamente cientes de que o tratamento analítico de conjunto de formas residuais e de depósitos correlativos, de ordem de antigüidade relativamente grande, pode acarretar enganos muito mais graves, e conduzir a anacronismos geológicos, que somente o futuro desenvolvimento das pesquisas e a descoberta de novos métodos e técnicas de trabalho poderão corrigir.

No fundo tais extensões metodológicas à seqüência de eventos cenozóicos do Planalto Brasileiro visa corrigir um pouco as deficiências de estudos intercientíficos que têm sufocado o desenvolvimento de alguns setores das ciências da Terra, entre nós. Sobretudo gostaríamos de despertar a atenção dos jovens geólogos e geógrafos brasileiros para a grande necessidade que 
temos de uma melhor integração de informações interdisciplinares, e para os resultados de exceção que podem ser obtidos, através de uma conjugação aberta e sistemática de diferentes métodos e técnicas de pesquisa. De nossa parte, sabemos que dentro de alguns anos os resultados sintéticos incluídos no presente ensaio terão uma validade muito relativa. Acreditamos, entretanto, na possibilidade de aplicação dos procedimentos aqui preconizados, com relação a compartimentos bem individualizados, situados no interior de uma província geológica qualquer, ou colocados em largos desvãos de províncias bem diferentes, ou, ainda, apenas relacionados com os limites meramente artificiais de uma quadrícula de trabalhos de campo. Com relação a esse último caso, sobretudo, a experiência nos demonstrou que são muito maiores os perigos de redução e de erros na síntese paleogeográfica, por parte dos que não possuem idéias mais gerais sobre a macrocompartimentação territorial. Nesse sentido, aliás, geólogos ortodoxos ou principiantes em Geologia e Geomorfologia podem incidir nos mesmos tipos de erros.

Insistimos no fato de que, ainda que houvesse informações paleontológicas suficientemente ricas para a datação de todas, ou, pelo menos, da maior parte das formações cenozóicas brasileiras, mesmo assim seria necessário intercalar os conhecimentos paleoclimáticos e paleomorfológicos acumulados, para se fazer uma verdadeira Paleogeografia. Isto porque, em Cronogeologia global, tão importante quanto a datação das camadas é o estabelecimento da sucessão dos eventos erosivos e deposicionais, que respondem mais diretamente pelos quadros regionais, passíveis de estudos de campo. E quer nos parecer que, para com um bloco de planaltos, tão ricamente compartimentado, como é o caso do chamado Planalto Brasileiro, existem oportunidades únicas para a aplicação dos métodos aqui utilizados. Dir-se-ia que as interferências tectônicas locais poderiam destruir todos os esquemas regionais normais, invalidando a aplicação dos princípios fisioestratigráficos aqui adotados. É um risco que devemos correr, assim como uma preocupação permanente que devemos ter, para eliminar, tanto quanto possível, o perigo derivado de situações tectônicas anômalas. Note-se, entretanto, que a paleotectônica complica sempre as interpretações regionais, qualquer que seja a área considerada e os métodos analíticos em utilização.
Existem sérios precedentes bibliográficos na discussão da integração dos dados geomorfológicos na síntese da história geológica ou da Paleogeografia de uma província geológicoestrutural qualquer.

O geólogo alemão Karl WALTHER (1924) que ocupou na geologia do Uruguai um pouco da posição que um Derby ou um Branner têm na Geologia Brasileira - teceu severos reparos críticos às idéias de Davis, conseguindo atingir a discussão do problema da viabilidade ou não do aproveitamento paleogeográfico dos conceitos genéricos sobre os chamados peneplanos. Pelo que se depreende da leitura de incisivos rodapés que enriquecem a monografia de Walther, intitulada Estudios geomorfologicos y geologicos Bases de la Geografia física del pais, o autor impugnava, de antemão, e baseado em sérios argumentos científicos, qualquer tentativa simplista de integração das idéias cíclicas de Davis, como pressupostos de parcelas da história geológica de um determinado território. Desta forma, em livro escrito e publicado em Montevidéu, no ano de 1924, o geólogo Karl Walther, baseado em seus conhecimentos de geologia regional e na sua grande experiência em pesquisas de campo, percebeu intuitivamente o quanto de inadmissível existia no esquema do ciclo vital dos relevos, quando antevisto sob o prisma de conjunto habitual de episódios paleogeográficos. Daí ter impugnado a aceitação tácita dos estágios teóricos de Davis como fatos integráveis nas reconstruções paleogeográficas de uma determinada região. E, hoje, somos obrigados a fazer justiça plena ao oportuno e incisivo senso crítico de Walther, mesmo porque seus escritos passaram inteiramente despercebidos no campo da crítica internacional, permanecendo à margem da bibliografia das obras de revisão ou de crítica à teoria de Davis.

Trinta anos passados, entretanto, podemos afiançar que, se é que Karl Walther tinha boas razões em relação à crítica das concepções davisianas, em absoluto tal fato pode significar uma impotência da Geomorfologia em face das reconstruções paleogeográficas. O próprio Albrecht PENCK (1928), o maior dos críticos clássicos da teoria do peneplano não hesitou em afirmar que a Geomorfologia tinha foros de capitulo final da Geologia Histórica (citação de MAACK in Os propósitos da Geografia Moderna..., 1956, p. 178, Curitiba).

Nos últimos vinte e cinco anos, os estudos geomorfológicos de caráter regional, levados a 
efeito na Europa Ocidental, conseguiram superar, implicitamente, a validade de tais discussões iniciais, pois a maioria deles incluiu como tarefa habitual a integração dos dados geomorfológicos em face dos conhecimentos fundamentais de ordem geológico-regional. Assim, através do exemplo sério e incontestável do estudo de Geomorfologia Regional, foi possível integrar fatos de história geológica com fatos da história fisiográfica ou geomorfológica, numa ampliação efetiva das dimensões da verdadeira Paleogeografia.

Muito embora estejamos bem alertados sobre as dificuldades inerentes às sínteses da história geomorfológica de um território de escala subcontinental como é o Planalto Brasileiro, em caráter provisório, teríamos os diferentes episódios paleogeográficos desenrolados do Cretáceo até o Quaternário, dentro do seguinte esquema, o qual é apenas uma primeira revisão da mirrada síntese por nós intentada há mais de 15 anos (AB' SÁBER, 1949, 1951).

1 - Deposição do Cretáceo continental, em ambiente de bacias intracratônicas, de subsidência moderada, comportando extensos lagos, planícies interiores subúmidas, e eventuais planícies de bolsones. Embaciamentos em quadrantes locais da bacias paleomesozóicas, que receberam depósitos de diversas origens desde o Devoniano até o Triássico. Extravasamento da sendimentação para áreas contíguas do Escudo. Eventualmente, recorrência sedimentar entre núcleos de bacias cretácicas contíguas. Aplainamentos por pediplanação nos núcleos de escudos expostos e nas bordas mais elevadas das bacias paleozóicas e mesozóicas (arenítico-basálticas). Formação de superfícies de cimeira no Brasil Central, no Nordeste, no Sudeste e altiplano basáltico de SE de Santa Catarina e NE do Rio Grande do Sul.

2 - Fase erosiva pós-Bauru, ou pós-Série Jatobá-Moxotó, com degradação lenta e rebaixamento das superfícies anteriormente formadas. Período eocênico ou eoceno-oligocênico. Epirogênese moderada. Formação de depósitos correlativos extensos e delgados, de grande importância para a caracterização dos novos aplainamentos: formações residuais de pequena espessura (Série Serra do Martins: formações detríticas dos altos tabuleiros) e potentes crostas de laterita. Climas ásperos, semi-áridos ou de savana. As superfícies aplainadas desse meio tempo encontram-se hoje em posição de cimei- ra, em situação de serem confundidas com as superfícies cretácicas. Exemplos de superfícies de cumiada, capeadas por sedimentos clásticos e eventualmente por cangas: superfície de Borborema (670 - 820m), superfície goianomatogrossense, capeadas por cangas (1.100 $1.300 \mathrm{~m}$ ). Idade: eoceno-oligocênica ou Oligoceno (?).

3 - Fase de circundesnudação posterior à Série Serra do Martins, formações dos tabuleiros de cimeira (NE de Minas e SE da Bahia) e superfície Itapecerica-São Roque. Longa época de desnudação marginal e de interdesnudação, estimulada pela mais forte e rápida fase ascensional do Planalto Brasileiro. Período de escultura da rede de grandes depressões periféricas do interior do Planalto Brasileiro. Durante algum tempo, escavação dominando sobre a plainação lateral, com evacuação de sedimentos finos através de drenagem pioneira de tipo exorreico.

4 - No término da fase de circundesnudação: aplainamento generalizado nos compartimentos embrionariamente criados. Retorno a climas secos moderados. Ameaça de desorganização da rede hidrográfica aberta, previamente definida. Depósitos residuais muito delgados, sujeitos à silicificação. Época das pedras-demós observáveis à base da Série Barreiras (Sergipe e Rio Grande do Norte) e no interior da Bahia. Possivelmente, época de silicificação de alguns sedimentos gondwânicos rebaixados e aplainados por desnudação.

5 - Fase erosiva, de degradação lenta, em climas subúmidos, pós-superfície das pedras-demós. Aplainamento pré-Barreiras, cortando diferentes formações (desde o pré-Cambriano até o Eoceno). Extensão gradual e progressiva de cobertura detrítica da Formação Barreiras, com aperfeiçoamento da pediplanação que retomou e rebaixou o aplainamento das pedras-demós. A Formação Barreiras é o grande documento do alto grau de aprofundamento territorial desta fase de aplainamento, constituindo, por si só, o mais notável depósito correlativo do Cenozóico brasileiro. Idade provável: miopliocênica (Tricart), pliocênica (datação clássica). Exemplos de superfícies contemporâneas ao fecho da sedimentação da Série Barreiras: superficie sertaneja (Nordeste Oriental e Nordeste Ocidental, Bahia), superfície neogênica de De Martonne (São Paulo), superfície sul-americana de King (extensas áreas do Brasil Oriental), superfícies de caráter nitidamente interplanálticas ou intermontanas, existentes no interior das 
depressões periféricas, desde o Nordeste até o Rio Grande do Sul, e o Centro-Oeste.

6 - Pequena fase de desnudação marginal nos bordos interiores da faixa de sedimentação da Formação Barreiras. Interdesnudação ao longo de incipientes drenagens pós-Barreiras. Processos de pedimentação restritos, porém sucessivos e alternados. Esboços sub-regionais de pediplanação. Alvéolos de pediplanação local, com planícies semi-áridas: Camassari, Jundiaí, Gravataí, interior do Quadrilátero Ferrífero. Níveis intermediários de cangas e de cascalheiros, ou de cascalhos retrabalhados recobertos e fossilizados por grandes blocos de canga (reverso da Serra de Santana, fazenda Analândia, em Rio Claro). Incisão de meandros em níveis intermediários ou diretamente a partir das superfícies interplanálticas. Diversas alternâncias entre mamelonização e pedimentação quaternárias no Brasil de Sudeste.

7 - Fixação da rede de drenagem atual em climas úmidos ou subúmidos. Destruição dos compartimentos endorreicos locais, com reintegração das drenagens ameaçadas de diluição durante o Pleistoceno Inferior e Médio. Concomitantemente com o alargamento das calhas aluviais e com a escultura de planícies alveolares, deposição dos cascalheiros que viriam a manter os baixos terraços da maior parte dos rios brasileiros.

8 - Retomada de erosão generalizada, de natureza climática, responsável pela escultura dos baixos terraços. Fase subúmida (?).

Preenchimento aluvial do fundo das planícies que se formaram à custa da retomada de erosão anterior, através de canais anastomosados. Fase inicialmente torrencial com afeiçoamento de seixos ou deposição de grandes massas de areias. Tais detritos arenáceos e rudáceos pressupõem uma fase mais seca ao iniciar-se a sedimentação basal das planícies atuais. Vegetação rala nas vertentes, com pavimentos detríticos delgados de 5 a $30 \mathrm{~cm}$, refletindo climas de savana e dominância de morfogênese mecânica. Decapitação gradual dos horizontes A e B dos solos anteriormente formados por decomposição mais funda e homogênea. $\mathrm{O}$ hiato entre essa fase e a que se segue parece ter coincidido com o advento do homem pré-histórico no Brasil.

9 - Transbordamento da sedimentação síltico-argilosa nas planícies de inundação holocênicas, herdadas da fase anterior, devido a mudanças climáticas no sentido dos climas úmidos.
Transformação generalizada das planícies de inundação do tipo braided channels (canais anastomosados, aparentemente numerosos no início) em planícies de inundação com meandros, em extensas áreas do Brasil tropical e subtropical úmido. Advento da vegetação florestal atual, por grandes áreas do Brasil tropical atlântico e Amazônia. Reaperfeiçoamento das vertentes descarnadas anteriores. Mamelonização das vertentes, por agregação de partículas arenosas e síltico-argilosas, com inhumação quase total dos paleopavimentos detríticos gerados no episódio climático anterior. Formação da roupagem atual das paisagens tropicais e subtropicais brasileiras. Desenvolvimento e expansão dos grupos humanos pré-históricos no Brasil.

10 - Uso desregrado dos solos tropicais e subtropicais brasileiros pelo homem histórico, à custa das atividades agrícolas extensivas e predatórias. Aceleração dos movimentos coletivos do solo nas vertentes íngremes. Acréscimo de detritos finos para o transporte fluvial e para sedimentação nas planícies de inundação.

Quinze anos após a publicação de nossos primeiros estudos a respeito do conjunto dos fenômenos de desnudação marginal do Planalto Brasileiro (1949), podemos reafirmar a existência indiscutível de vastas calhas de circundesnudação e desnudação periférica nos mais diferentes quadrantes desse conjunto de planaltos inter e extratropicais. Podemos afirmar, ainda, sublinhando uma idéia que estava implícita em nossos primeiros trabalhos, que tais fenomenos gerais de circundesnudação e desnudação marginal foram os de maior importância no desenvolvimento da macrocompartimentação topográfica de nossa principal área de planaltos, onde, à exceção feita do caso da Fossa do Paraíba, não existem grandes compartimentos tectônicos. Essa, aliás, é a grande diferença entre a compartimentação interior das porções centro-orientais da América do Sul e da África, pois em território africano a quota de compartimentos tectônicos é muito maior e paisagisticamente mais expressiva (rift valleys, lagos tectônicos, montanhas-em-blocos de falhas).

O termo circundesnudação deve continuar a ser usado, ainda que em um sentido puramente global, incluindo apenas a idéia de prolongados processos erosivos de arranjo circular ou semicircular, em torno de bacias ou de núcleos de escudo em abóbada. Devido aos exemplos brasileiros, pode-se ter como certo que é a circundesnudação, provocada por arranjos estruturais dis- 
cordantes e pela existência de verdadeiras faixas tendenciais para a erosão diferencial, tanto pode ser feita em torno de bacias como em torno de núcleos bombeados de escudos. Em seu conceito não pode haver idéias genéticas preconcebidas, pois em sua elaboração funcionaram, alternadamente, processos de escavação e de aplainamentos relacionados com diferentes modalidades de sistemas morfoclimáticos intertropicais. Nesse sentido as calhas de desnudação marginal, que tão bem caracterizam a macrocompartimentação topográfica do Escudo Brasileiro, são tão-somente o resultado de uma soma de saldos complexos de formas de relevo, elaboradas e retrabalhadas sucessivamente, por sistemas morfoclimáticos intertropicais. Além do mais, existem forças de capacidade imponderável nesse conjunto de processos pretéritos, já que é quase impossível calcular a contribuição erosiva e modeladora das diversas fases de climas agressivos que devem ter agido na formação das depressões periféricas brasileiras, no decorrer do Terciário. Do mesmo modo, é praticamente impossível de ser avaliada a contribuição subsidiária das pequenas fases de tectônica residual que podem ter auxiliado o desenvolvimento e a amplificação das aplainações no interior de tais compartimentos desnudacionais.

Os compartimentos deprimidos do Planalto Brasileiro, oriundos dos fenômenos de desnudação terciários, do ponto de vista conceitual de caráter geomorfológico-estrutural, enquadram-se em uma série de grandes tipos de relevo, a saber: 1. depressões periféricas subseqüentes, situadas em torno de bacias ou circundando parcialmente núcleos de escudos em abóbada, com afloramentos de rochas sedimentares da porção inferior da bacia no desvão deprimido (depressão periférica paulista, depressão periférica gaúcha, depressão periférica do médio São Francisco, depressão periférica do Paraná, trechos da depressão periférica catarinense-paranaense ao norte e nordeste da Serra do Paredão, trechos da depressão periférica centro-sudoeste de Goiás); 2. depressões monoclinais em áreas de cuestas desdobradas ou sucessivas (depressões monoclinais matogrossenses, situadas entre cuestas mantidas por estruturas triássicas, carboníferas e devonianas; depressões monoclinais do reverso da Serra Grande no Piauí, talhadas entre cuestas sucessivas mantidas por diferentes formações devonianas e carboníferas; depressões monoclinais descontínuas do Alto Paraná, nos Estados do Paraná, Santa Catarina, São Paulo e
Goiás, situadas entre os reversos de cuestas de diversas idades - devonianas, carboníferas, permianas, triássicas e cretáceas); 3. depressões marginais com forte eversão e ações da pediplanação moderna em áreas de antigas depressões periféricas subseqüentes ou em zonas de boutonnières (pediplano Cuiabano, primeiro planalto do Paraná, pediplano oriental do Ceará, pediplanos do Norte de Goiás e sudoeste de Maranhão). Tais áreas de eversão de prolongada e complexa história denudacional são particularmente expressivas à margem das velhas escarpas devonianas das bacias do Maranhão-Piauí (Serra Grande) e do Paraná (Serra de São Joaquim, Chapada dos Guimarães, Serra Azul); 4. depressões marginais com eversão e formação de bacias detríticas modernas ou em processo (região da Bacia de Curitiba, Pantanal Matogrossense).

Existem sensíveis diferenças de possibilidades para a caracterização genética dos grandes tipos de superfícies aplainadas brasileiras. Por mais paradoxal que pareça, as superficies mais fáceis de serem caracterizadas são as topografias fósseis, independente de sua maior ou menor antigüidade (paleoplanos pré-devonianos do Ceará-Piauí, de Mato Grosso e do Paraná, superfície pré-glacial carbonífera de São Paulo). Já com relação às superfícies de cimeira a situação é inteiramente diversa, pois aí estamos em presença de problemas genéticos quase que impossíveis de ser resolvidos. Na realidade, tais plainos de erosão antigos - hoje colocados nos altos de maciços - já puderam ser reduzidos, rebaixados e retrabalhados em relação à sua superfície original, ao mesmo tempo em que muitos deles perderam seus depósitos correlativos, penecontemporâneos aos aplainamentos, ganhando muitas vezes crostas, películas detríticas e solos, de idade muito mais recente (como é o caso dos depósitos do reverso da Serra de Santana em São Paulo). Entrementes, as superficies interplanálticas das depressões periféricas subseqüentes ou das áreas de eversão extensiva, oriundas todas do período final de afeiçoamento neogênico, podem ser caracterizadas, quase que sem exceção, como áreas de pediplanação intertropicais. Seu aperfeiçoamento certamente se deveu a fases ativas de pediplanação, entremeadas com fases de degradação lenta, balizadas por níveis de base gerais pretéritos. Tais fases ativas de pediplanação, por seu turno, devem ter sido estimuladas por uma combinação de processos, na qual estiveram presentes as variações 
climáticas típicas das áreas intertropicais, comportando fases agressivas de erosão dos solos, estimuladas ou não por discreta epirogênese positiva. Evidentemente, tais fatos foram muito mais sensíveis no interior e nos bordos dos principais compartimentos de relevo elaborados no Planalto Brasileiro no decorrer do Terciário. Disso decorre não se poder isolar o estudo das depressões periféricas do estudo das superfícies aplainadas, quando se tem em vista avaliar o grau da participação de ambos na macrocompartimentação do Planalto Brasileiro.

Uma crítica perfeitamente aceitável às idéias aqui expostas, sobre o conjunto dos fenômenos de pediplanação neogênica, seria aquela que pusesse em dúvida a contemporaneidade de tais aplainações. $\mathrm{Na}$ realidade, ainda que na segunda metade do Terciário brasileiro pareça terem existido demorados períodos de climas cálidos - talvez variando de subúmido a semiárido moderado -, de modo algum tal pressuposição pode garantir qualquer coisa de mais objetivo sobre o zoneamento climático do território brasileiro, na época. Como geógrafos, que somos, negamo-nos terminantemente a pensar que, em relação a um território tão grande e já relativamente compartimentado, pudesse haver uma inexistência completa de zoneamento climático. Ainda que os níveis de pedimentos dos bordos das depressões interplanálticas pareçam ser grosso modo correspondentes entre si; e, ainda mesmo que os níveis e outras feições geomórficas quaternárias pareçam ter sido elaboradas a partir de superficies regionais equivalentes, há que ser prudente na interpretação da aparente contemporaneidade de tais pediplanos. Daí preferirmos a expressão aplainamentos neogênicos para designá-los, já que seu afeiçoamento, mais pronunciado, deve ter sido feito entre o Mioceno e o Plioceno, culminando, às vezes, no próprio Quaternário Inferior. Desta forma, sua penecontemporaneidade é muito frouxa, havendo motivos para se pensar que o seu aperfeiçoamento foi sucessivo ou alternado, havendo a possibilidade de, entre alguns deles, ter havido a diferença de uma idade ou época, dentro dos largos limites de um mesmo período geológico.

Estamos bem certos, entretanto, de que o Oligoceno, o Mioceno e o Plioceno tenham sido os períodos máximos de aperfeiçoamento denudacional dos compartimentos interiores do Planalto Brasileiro, nos moldes que vimos de expor. Não existem depósitos do Oligoceno em qualquer parte dos grandes compartimentos topográficos de nossos planaltos inter e extratropicais, enquanto que os depósitos miocênicos típicos pertencem apenas às áreas marginais subsidentes e falhadas do grande bloco de platôs que é o Planalto Brasileiro (Baixo AmazonasNordeste do Pará e Fossa de Pelotas). Tais áreas de sedimentos marinhos do Mioceno, situadas próximo a fossas que facilitaram a ingressão dos mares miocênicos, atestam que a massa cratônica principal do Escudo Brasileiro estava ainda sujeita a fortes ações epirogênicas por essa época. Assim, a pediplanação no interior da rede de depressões periféricas brasileiras deve ter sido aperfeiçoada pelo estímulo dúplice de variações climáticas intertropicais, aliadas à movimentação tectônica ascendente do conjunto, em oposição ao que acontecia nas citadas fossas. Aliás, os documentos sedimentários existentes nessas duas áreas miocênicas do Brasil atlântico constituem uma das raras bases sólidas para avaliações paleoclimáticas sobre um dos períodos denudacionais básicos que muito teve a ver com a macrocompartimentação do território brasileiro. E é de se esperar que sedimentólogos, estratígrafos e geomorfologistas possam tirar melhor proveito das informações contidas nos aludidos depósitos, colocados em áreas tão separadas como o Pará e o Rio Grande do Sul.

Ao contrário do que a bibliografia geomorfológica brasileira parecia indicar até uns dez ou quinze anos atrás, nosso país é bastante rico em exemplos regionais de estruturas dômicas, sobretudo no que diz respeito à presença de núcleos de escudo em abóbadas de grande raio de curvatura. É verdade que, nas regiões intertropicais, os aplainamentos deslocados na posição de cimeiras, ao par com os seus complementos, representados por aplainamentos interplanálticos, conseguem mascarar sensivelmente os grandes edificios estruturais de conformação dômica. Fato, aliás, que se torna mais verdadeiro, devido a certas particularidades dos processos climáticos tropicais, os quais decompõem profundamente as rochas, escondendo e dificultando a observação das relações entre a estrutura e as feições do relevo. Disso decorre que, no Brasil, mesmo em situações estruturais de ordem de grandeza reduzida, e, que em outros climas poderiam criar paisagens morfoestruturais típicas, existem dificuldades inumeráveis para a identificação do esque- 
ma estrutural de tais áreas. Mais recentemente, as fotografias aéreas têm resolvido satisfatoriamente a locação de pequenas estruturas e anomalias regionais. Entretanto, somente através da cartografação geomorfológica, em escala de mapas, pudemos atinar com a presença de casos de estruturas macrodômicas nos escudos orientais sul-americanos.

$\mathrm{Na}$ identificação de domos cristalinos ou de núcleos de escudo em abóbada, a presença de drenagens radiais-irregulares ou divergentes, de âmbito regional, constituiu uma chave de primeira ordem (Nordeste Oriental, Sudeste do Rio Grande e Nordeste do Uruguai, Centro-Sul de Goiás, Brasil de Sudeste). Perseguindo sistematicamente o critério da presença desses dispersores divergentes ou macrorradiais, pudemos estabelecer melhor a tectônica moderna dos diferentes núcleos de escudo, anteriormente apenas suspeitados. Trata-se de uma série de bons exemplos, dignos de registro nos quadros da Geomorfologia Brasileira, pois todos eles refletem, em sua evolução tectônica e geomorfológica e nos quadros atuais de seu relevo, as influências da tectônica dômica e da epirogênese, assim como apresentam marcos das flutuações climáticas do Terciário e Quaternário.

Entretanto, mesmo as áreas dômicas de menor envergadura, tais como a de Itabaiana, em Sergipe, ou de Lajes, em Santa Catarina, apresentam feições morfoestruturais e morfoclimáticas dignas de maior reparo.

O domo de Itabaiana - estudado pelos geólogos da Petrobrás e por nós próprios -, situado à retaguarda dos tabuleiros sublitorâneos de Sergipe, contém toda a chave da evolução paleoclimática moderna da zona de transição entre os climas tropicais úmidos costeiros e os climas semi-áridos do interior. Em sua depressão central, após os efeitos da pediplanação neogênica, houve uma série de episódios erosivos e deposicionais recentes com a formação de vários níveis de pedimentos obseqüentes, paleocanais torrenciais e paleopavimentos detríticos, sem falar na formação de um pequeno campo de dunas interiores. Trata-se de depósitos que conservam um valor paleoclimático muitas vezes superior àqueles conhecidos nas extensões monótonas dos sertões interiores.

Em Lajes - em uma área estudada por Glycon de PAIVA (1933), pelos geólogos da Petrobrás e por Francisco TAKEDA (1958) - em pleno Planalto Basáltico, entre 900 e 1.100 metros de altitude, existe uma outra estrutura dômica, relativamente complexa, exibida numa região em que as intrusões alcalinas tardias forçaram um bombeamento do espesso tampão de lavas anteriormente formado. Dessa forma, enquanto o domo de Itabaiana é pré-Cambriano, o domo de Lajes é pós-Triássico, no que se refere à idade da deformação em abóbada. No interior da boutonnière de Lajes, a dissecação pós-cretácica contribuiu para esvaziar a abóbada superior basáltica e parte das coberturas triássicas, permianas e carboníferas. Entrementes, ao contrário do que acontece em Itabaiana, não houve qualquer retenção apreciável de depósitos detríticos modernos na depressão central do domo de Lajes, muito embora sejam visíveis as marcas de dois níveis de pedimentos quartenários e de um nível de baixo terraço fluvial (strath terrace), além de alguns depósitos de planícies aluviais com camada cascalhosa basal, de stone lines inhumadas descontinuamente nas vertentes colinosas. Pode-se afiançar que o domo de Lajes foi dissecado no decorrer do Terciário, ligeiramente aplainado no Neogeno, e sujeito a algumas retomadas de pediplanação e terraceamento no Quaternário.

$\mathrm{Na}$ depressão periférica paulista, entrementes, onde a pediplanação interplanáltica neogênica foi muito completa, os domos lacolíticos perderam quase que por completo o seu caráter presumível de dome mountains, transformandose em escombros de estruturas dômicas, ou seja, em meros relevos residuais da superfície aplainada neogênica. É de se anotar que o morro de Araçoiaba, estrutura semidômica e parcialmente falhada, oriunda de intrusões alcalinas, similares às de Lajes, permanece como paisagem de exceção, bem acima da superfície pediplanada neogênica da depressão periférica paulista, conseguindo merecer a um tempo o título de maciço intrusivo exumado, estrutura semidômica e relevo residual. Assim, enquanto em Lajes houve a formação de uma verdadeira boutonnière, na área de Araçoiaba ficou um maciço intrusivo ilhado na vasta depressão pediplanada paulista.

O Nordeste Oriental e o Sudeste do Rio Grande do Sul são áreas dos escudos orientais sul-americanos onde é particularmente expressiva a presença de núcleos cristalinos de conformação geral dômica. Trata-se de núcleos de escudo deformados em abóbada, a partir de diferentes épocas geológicas, um tanto inferiores em áreas aos casos do Centro de Goiás e do Brasil de Sudeste, porém muito mais fáceis de serem identificados e delimitados cartograficamente. Ambos possuem uma ordem de grandeza 
territorial, grosso modo semelhante: são áreas de relevo que oscilam entre 30.000 e $50.000 \mathrm{~km}^{2}$ de área, incluindo-se, portanto, nas massas topográfico-estruturais de $3^{\mathrm{a}}$ ordem de grandeza, na classificação de CAILLEUX-TRICART (1956). Trata-se, ainda, de regiões cuja deformação em abóboda se fez à custa de embaciamentos lentos ou progressivos, em relação sobretudo aos quadrantes interiores (ocidentais, setentrionais e meridionais) e com falhamentos importantes nas fachadas atlânticas de seus respectivos territórios. Se no Nordeste Oriental existem alturas de até 1.150 metros nos altos dos antigos maciços regionais, é digno de nota que a leste de seu núcleo saliente principal foram localizadas fossas cretácicas de até 4.000 metros de profundidade (Sergipe-Alagoas). No Rio Grande do Sul, onde os altos aplainados do maciço antigo regional situam-se em torno de 400-460 metros, foram descobertas, também a leste da saliência continental do núcleo de escudo regional, fossas tectônicas de idade miocênica, com até 1.500 metros de profundidade (Bacia de Pelotas). Tais fatos conferem aos mais notáveis núcleos em abóboda do Brasil Oriental um caráter de áreas semidômicas ou, pelo menos, de áreas dômicas assimétricas afetadas por falhamentos modernos.

O núcleo bombeado da Borborema somente adquiriu tal forma a partir do Cretáceo, com reativação da tectônica dômica por mais de uma vez até o Quaternário. Entrementes, o núcleo em abóbodas do Sudeste do Rio Grande e do Nordeste do Uruguai esboçou-se a partir do Carbonífero, tendo sofrido repronunciamentos sucessivos no Permiano e no Triássico e após a formação da superfície da Campanha. O bordo oriental da Borborema foi quebrado a partir do Cretáceo, com possíveis reativações de falhas após o Eoceno e o Oligoceno, enquanto o bordo do Escudo Uruguaio-Sul riograndense, que até o Paleógeno devia se estender muito para leste, foi quebrado a partir do Mioceno, com possíveis reativações de tectônica quebrável entre o Plioceno e o próprio Quaternário Inferior.

No que tange à rede de fenômenos de circundesnudação nos planaltos interiores de nosso país, ambos esses núcleos dômicos, de grande envergadura espacial, foram teatro de uma complexa e extensa circunvalação denudacional, no decorrer do Terciário. Tais fenômenos de circundesnudação foram exteriores nos dois casos, ao núcleo saliente das estruturas antigas, fato que contribuiu para a ressalientação de maciços centrais, correspondentes ao core cristalino do bombeamento tectônico regional. Dessa forma, a compartimentação topográfica que se fez em torno de tais maciços de conformação dômica contribuiu para esboçar o mosaico das grandes províncias estruturais e morfológicas que tão bem caracterizam as aludidas áreas do território brasileiro. Com isso, as depressões periféricas gaúchas e nordestinas pediplanadas responderam a um tempo pela macrocompartimentação da hinterlândia e pela exumação e ressalientação de embasamentos dômicos pré-cambrianos ou pré-devonianos.

Tanto o Sudeste do Rio Grande do Sul, quanto a Borborema, a despeito de estarem separados entre si por mais de 3.000 quilômetros de interespaço e de constituírem áreas climáticas bem diversas, apresentam esquemas de superfícies aplainadas, muito aparentadas. Aquela dupla série de superfícies colocadas em planos diferentes, a que já aludimos superficies de cimeira e superficies interplanálticas está igualmente presente tanto na terra gaúcha quanto nas terras nordestinas. Ambas contribuíram, aliás, para a criação de panoramas e horizontes, pois, sobretudo as superfícies interplanálticas tiveram uma grande participação na elaboração das paisagens da Campanha e do Sertão (na acepção nordestina do termo). Notese, porém, que existem diferenças dignas de ponderação, no que tange aos desdobramentos regionais de tais séries de superfície, pois no Rio Grande a superfície de Caçapava do Sul é de uma individualidade única e ímpar, enquanto as superfícies de cimeira nordestina encontramse desdobradas e até mesmo tresdobradas. Por outro lado, apenas na área nordestina existem coroamentos detríticos importantes na cimeira dos planaltos cristalinos, depósitos esses que possuem a categoria de depósitos correlativos dos aplainamentos superiores (superfície de Teixeira ou da Borborema) e representam excelentes documentos no campo das indicações paleoclimáticas. No Sul, os restos de depósitos tidos como testemunhos marginais outliers das formações cretácicas uruguaias - situados, grosso modo, nos flancos superiores da porção sul-ocidental do Escudo (meseta de Santa Tecla) - não foram estudados, ainda, sob uma boa visão paleogeográfica e geomorfológica, restando inteiramente aberta a discussão dos mesmos, nessa ordem de idéias.

Uma comparação minuciosa entre as áreas sujeitas a pediplanação moderna nos comparti- 
mentos deprimidos, de caráter interplanáltico, do Nordeste e do Rio Grande do Sul, também deixa margem para se perceber, em algumas, diferenças ponderáveis que interessam à própria compreensão da intensidade dos processos denudacionais que afetaram as duas regiões. A largura média da depressão periférica gaúcha (setor Baixo Jacuí e setor do vale do Santa Maria) oscila entre 100 e 120 quilômetros, permanecendo sempre confinada aos limites da própria depressão periférica subseqüente regional. Entrementes, as áreas sujeitas a processos extensivos de pediplanação na Bahia e no Nordeste ultrapassam em muito tais cifras, chegando a alcançar de 250 a 300 quilômetros de extensão lateral. E se é verdade que no domínio nordestino de pediplanos sertanejos existem, em diversas regiões, campos de inselbergs, quebrando a monotomia dos pediplanos, não menos verdade é que, ali, os plainos de erosão semiáridos cortam principalmente rochas cristalinas e cristalofilianas antigas, dotadas de sensíveis diferenças de resistência à erosão, em climas os mais diversos (quartzitos, itacolumitos, granitos pouco diaclasados, migmatitos e xistos). Se no Rio Grande as superfícies interplanálticas modernas ficaram embutidas entre as frentes das cuestas basálticas e os bordos de erosão dos quadrantes interiores do Escudo Uruguaio-Sul riograndense, no Nordeste Brasileiro, pelo contrário, os pediplanos sertanejos escapam às áreas de depressões periféricas subseqüentes propriamente ditas, extravasando coalescentemente pelas mais variadas direções, por entre relevos apalachianos talhados em rochas do próprio embasamento e através dos desvãos de chapadas cretácicas isoladas. O próprio isolamento das chapadas sedimentares cretácicas, entre si, deveu-se à extensão dos pediplanos modernos por alguns dos altos fundos do embasamento, que outrora compartimentava em sinclinais sucessivas a bacia mesozóica regional, em sinclinais sucessivas.

A amplitude dessa pediplanação extensiva tanto pode ser observada nos sertões semi-áridos da Bahia-Pernambuco-Alagoas, como nas porções interiores dos Estados da Paraíba, do Rio Grande do Norte e Ceará. Na realidade, os pediplanos, que em Pernambuco estão embutidos entre a Chapada de São José do Moxotó e a Serra de Triunfo, para oeste, contornam a Borborema à altura da Serra Talhada, dirigindose para o norte, onde se vão reunir aos pediplanos paraibanos e cearenses. Dessa forma, os pediplanos do triângulo interior BahiaPernambuco-Alagoas se interpenetram pelo largo colo, situado entre a Borborema e a Chapada do Araripe, sem uma solução de continuidade digna de maior ponderação, indo reunir-se aos pediplanos do sul do Ceará e oeste da Paraíba. Daí por diante, e de uma forma relativamente irregular e descontínua, internam-se pela região acidentada do Centro do Ceará, para, depois, atingir a área dos pediplanos fronteiriços do Rio Grande do Norte. Por outro lado, vão atingir os pediplanos ocidentais do próprio Ceará, recortados a centenas de metros abaixo da superfície fóssil devoniana da Serra Grande, numa das áreas de eversão mais notáveis de nosso país. Tal fato nos leva a concluir que os pediplanos que se iniciam na área de eversão situada ao norte da Chapada de São José (cretácica) ramificam-se até atingir a área de eversão situada a leste da Serra do Ibiapaba (Devoniano). E, mais do que isso, nos leva à constatação de que a força aplainadora dos processos morfoclimáticos interferentes no domínio dos climas semi-áridos brasileiros, foi muitas vezes maior do que as forças erosivas que agiram no domínio dos climas subtropicais do Sul do Brasil.

Em todo o chamado Planalto Brasileiro, talvez apenas a região sul-amazônica apresente tão largas e aperfeiçoadas áreas de aplainamentos modernos, as quais, entretanto, por estarem hoje sujeitas a climas quentes e úmidos e recobertas por florestas, perderam grande parte dos caracteres morfológicos originais, que certamente tiveram. Por seu turno, as outras áreas pediplanadas do Escudo Brasileiro - relacionadas com fase de aperfeiçoamento ou ampliação derradeira das ações de aplainamento terciários - constituem setores muito mais restritos e descontínuos, tendo sofrido modificações geomorfológicas apreciáveis no decorrer do Quaternário, com penetrações recentes de diferentes tipos de vegetação tropicais e subtropicais úmidos (matas, cerrados e pradarias mistas) (AB' SABER, 1964). Disso tudo resultou que os pediplanos baianos e nordestinos podem ser considerados como a maior e mais extensa bem como a mais típica e melhor preservada área de pediplanação moderna apresentada pelo território brasileiro.

É-se obrigado a reconhecer que, no caso, a extensão desmesurada da pediplanação importa em uma certa perda de sua expressão como elemento de caracterização da compartimentação 
topográfica regional. Nesse sentido, sua participação no conjunto das paisagens nordestinas muitas vezes somente pode ser percebida com exatidão quando vista sob o prisma dos mapas geomorfológicos de escala relativamente pequena. Não menos verdade, porém, é que, nos setores em que os pediplanos se aproximam dos maciços antigos ou cuestas, o contraste entre os relevos vigorosos de tais elevações, em face das rasas baixadas semi-áridas sertanejas, torna-se particularmente sensível, apresentando magníficos cenários topográficos e morfológicos.

Importante é lembrar que tais aplainamentos extensivos circunscritos a depressões periféricas ou delas muito extravasados foram episódios de períodos denudacionais longos do Terciário, porém com a provável interferência de lapsos erosivos particulamente agressivos, correspondentes a fases de climas de transição. Note-se, entretanto, que em ambos os casos, aqui especificamente tratados, até mesmo a ação dos chamados climas agressivos se processou em condições de drenagem exorreicas e, certamente, em períodos tectônicos de soerguimento epirogênico, não acompanhados de falhas geomorfologicamente contrárias. No Nordeste foi criada uma faixa importante de sedimentos detríticos, nas derradeiras fases de afeiçoamento dos pediplanos sertanejos, colocada em forma de franja costeira, larga e contínua, correspondente ao grupo Barreiras, enquanto que no Rio Grande do Sul houve sedimentação tenuemente análoga, apenas no Quaternário Inferior.

No domínio dos sertões semi-áridos, a paisagem que se vê à curta distância, aquela que é sentida e na qual se anda, é sempre oriunda da herança das flutuações climáticas quaternárias. Por oposição, aquela que se vê no horizonte relativamente raso dos sertões baixos corresponde sempre a uma herança das aplainações de muito maior escala, ocorridas no Neogeno. Assim, os pediplanos sertanejos parecem ser o saldo de velhas flutuações climáticas, de maior espaçamento e duração, enquanto os níveis embutidos, os compartimentos alveolares dissecados e terraceados, os raros campos de dunas interiores (Camaçari), coberturas de dunas adelgaçadas, pedimentos embutidos em desvãos de interflúvios mais altos, são todos meras expressões do modelado flutuante do Quaternário regional.

Identicamente, no Rio Grande do Sul, a paisagem de detalhe das coxilhas, com seus níveis de colinas mamelonizadas, colocados em diferentes planos rasos, é sempre herança das derradeiras flutuações climáticas dessa área subtropical do país. No entanto, os horizontes desdobrados da Campanha, os planos mais elevados das coxilhas divisoras, existentes em diversos setores do cinturão da depressão periférica gaúcha, constituem os níveis remanescentes das aplainações dos fins do Terciário. Ainda uma vez, ali, o relevo em que se anda, se sente e se vê, à curta distância, é sempre o resultado complexo das flutuações climáticas quaternárias, enquanto que a superfície da Campanha, balizada pela linha de horizonte das altas coxilhas, constitui o saldo das aplainações da segunda metade do Terciário, em terra gaúcha.

A nosso ver, as velhas dúvidas sobre a idade dos pediplanos interplanálticos regionais de nosso país (Nordeste, São Paulo, Rio Grande do Sul), fundamentalmente, não mais procedem, pois o nível geral de tais áreas aplainadas, que possuem extensão superior a 100 quilômetros de largura, só pode ter sido elaborado e aperfeiçoado quando da vigência de períodos climáticos longos, de milhões ou dezenas de milhões de anos de duração, entremeados por flutuações climáticas agressivas, as quais somente puderam aperfeiçoar os planos erosivos sujeitos à degradação lenta. Pela sua duração, evidentemente, tais condições paleogeográficas e paleoclimáticas terão de ser buscadas em fases pré-quaternárias, anteriores às rápidas flutuações climáticas $\mathrm{e}$ eustáticas, que respondem tão-somente pelo modelado de detalhe. Assim sendo, todos os pediplanos interplanálticos brasileiros - antevistos sob a perspectiva que acabamos de ponderar - devem ter sofrido o seu último afeiçoamento macrorregional, nos fins do Terciário (Plioceno Superior), grosso modo na fase de ampliação máxima da faixa de pedimentação detrítica do Grupo Barreiras, como de há muito se suspeitava (ANDRADE, 1958). Identicamente, pode-se afirmar que a macrocompartimentação geral do Planalto Brasileiro foi completada no Terciário Superior, processando-se daí por diante, em pleno Quaternário, a remodelação de detalhe, realizada por pequenas retomadas da erosão linear, alternadas com retorno da pedimentação e por terraceamento e fases de aluviação. Estamos absolutamente convencidos de que até o Plioceno Superior a paisagem dos compartimentos interiores do país ainda era muito homogênea, mesmo em relação a áreas relativamente afastadas entre si e que, em contrapartida, no 
decorrer do Quaternário, devido às rápidas flutuações climáticas e eustáticas, processou-se uma modelagem complexa e altamente diferenciada, que criou os quadros menores de relevo e de estrutura de paisagem e de solos, hoje observáveis nas mais diversas depressões periféricas e nos compartimentos interiores, herdados das aplainações dos fins do Terciário. Tanto os baixos chapadões e colinas da depressão periférica paulista (recobertos por matas e cerrados), como as coxilhas mamelonares do interior do Rio Grande (recobertas por pradarias mistas) ou, ainda, as suaves colinas de solos rasos e frágeis do Nordeste semi-árido (revestidas pela áspera vegetação das caatingas) são expressões diretas de um zoneamento climático regional, relativamente novo, que contribuiu para a escultura de minúcia dos macrocompartimentos herdados da fisiografia terciária, constituindo ainda uma notável herança das interferências de processos macroclimáticos quaternários em áreas inter $\mathrm{e}$ extratropicais.

Ao que tudo leva a crer, os embaciamentos principais das áreas de bacias mesozóicas do Nordeste Oriental e da Bahia, a princípio se fizeram a partir de depressões ou sinclinais restritas - e, portanto, isoladas entre si - com posterior recorrência dos depósitos superiores, devido a uma transgressividade progressiva, para usar de uma expressão bastante sugestiva de Wilhelm Kegel (1956). O fato de algumas chapadas cretácicas, relativamente isoladas (porém, pertencentes à mesma província geológica e geomorfológica), corresponderem a sinclinais bem marcadas parece comprovar tais asserções (casos do Araripe e da Chapada de São José do Moxotó). Mais do que isso, essa conformação da base da província cretácica regional constitui um sério documento a favor da idéia de que, ao findar o ciclo da sedimentação cretácica na região, os núcleos de sedimentação, inicialmente isolados, puderam se reunir coalescentemente em torno da Borborema, quase que a insulando por completo, e, talvez mesmo, a recobrindo parcialmente, na forma aproximada dos chamados domos de compactação. Daí o aspecto atual, divergente ou radial irregular da drenagem desse núcleo dômico do Nordeste Oriental, a que temos designado por núcleo nordestiniano do Escudo Brasileiro. Os rios conseqüentes radiais que saíram do centro dessa grande abóbada, na direção de sua periferia, devem ter estabelecido passagens conseqüentes dotadas de um certo grau de permanên- cia como eixo de drenagem exorreicas. Tais elementos pioneiros da antiga drenagem pós-cretácica da região puderam entalhar verticalmente a cobertura semi-dômica cretácica, fato presumivelmente muitas vezes interrompido, devido às modificações dos sistemas de erosão no decorrer do Terciário e Quaternário.

Não temos dúvidas de que, tanto em relação ao Nordeste como até mesmo em relação ao Rio Grande do Sul, as fases de entalhamento vertical e as fases prolongadas de pedimentação alternaram-se no tempo, ao longo das seções conseqüentes de vales pioneiros. E menos dúvidas ainda nos restam sobre o fato de tais modalidades de erosão terem sido particularmente agressivas durante as fases de transição climática inter ou subtropicais. Entrementes, há que se concordar quanto ao fato de que, no domínio semi-árido do território brasileiro, houve uma pediplanação mais extensa do que em outras áreas tropicais e subtropicais do país.

Temos sérias razões para pensar que as fases máximas de erosão de talvegue, com repronunciamento das secções transversais dos vales subseqüentes e conseqüentes, tenham sido as de transição dos climas mais secos para os mais úmidos, enquanto que as fases máximas de pedimentação ou mesmo de pediplanação terse-iam efetuado na transição dos climas úmidos para os secos ou semi-áridos moderados.

As razões básicas dessa agressividade máxima das duas modalidades de erosão - uma linear e outra lateral - corresponder ao clima de transição são relativamente fáceis de ser explicadas, graças às idéias combinadas de uma série de pesquisadores que vêm cuidando da geomorfologia das regiões inter e extratropicais. Notese que freqüentemente se fala em climas agressivos, aplicados aos climas de transição; entretanto, o que se visa sublinhar é o fato de que os climas de transição das regiões intertropicais correspondem sempre a fases erosivas particularmente agressivas, do ponto de vista morfoclimático, devido à notável quebra dos equilíbrios preexistentes por eles acarretados. Em outras palavras, toda fase de transição climática, geologicamente brusca, interfere radicalmente no equilíbrio das condições biológicas e, conseqüentemente, no equilíbrio geral das vertentes, na estrutura superficial das paisagens, na catena regional de solos e no domínio hidrológico regional. Tais fatos parecem ser particularmente atuantes nas áreas que já possuem uma certa compartimentação herdada de fases erosivas anteriores e sobretudo quando o assoalho ou 
um dos bordos de tais compartimentos comportarem rochas cristalinas ou cristalofilianas, a exemplo do que acontece nos compartimentos interiores do relevo nordestino e baiano.

André Cailleux, em diversas oportunidades, tem chamado a atenção dos geomorfologistas a respeito da importância dos chamados climas agressivos. Pierre BIROT (1959), em palavras de introdução a uma sintética "Geografia Física Geral da Zona Intertropical", escreveu as seguinte ponderações:"il faut avoir présent a l'espirit avant d'aborder cette étude, c'est que, morphologiquement, les périodes les plus actives ne sont pas nécessairement les périodes où un certain climat a duré le plus longtemps. Peut être les formes que nous avons sous les yeux $n$ 'ont pas été élaborées dans les periodes de stabilité climatique, par conséquent ne représentent pas un climax, mais dans des périodes de transition, des périodes de crise climatique où l'érosion était exagerée. A ce point de vue il y a une différence entre les sols et les formes. Les sols, au contraire, ont été élaborés dans des périodes de stabilité". Consideramos tais fatos como absolutamente essenciais para a exata compreensão da evolução dos compartimentos interiores dos planaltos intertropicais, pois não fora o fato de a catena de solos ter-se amadurecido durante os períodos de estabilidade climática, relativamente prolongados, não poderia haver agressividade morfoclimática, nas fases de transições climáticas bruscas.

Tal linha de pensamento, adquirida graças, sobretudo, aos novos conhecimentos geomorfológicos auridos em contato direto com as paisagens morfológicas das áreas intertropicais, parece ser a tendência e a conquista mais importante da Geomorfologia de linhagem climática, nos últimos quinze anos. Alinham-se entre os que assim pensam Jean Dresch, Pierre Birot, André Cailleux e Jean Tricart.

Jean Dresch, baseado em seus conhecimentos sobre a geomorfologia intertropical da África e do Brasil, tem procurado demonstrar, em mais de uma oportunidade, que as plainações laterais extensivas nas regiões intertropicais estão de alguma forma amarradas às transições climáticas, que implicam uma modificação do úmido para o seco. Segundo o pensamento de mestre Dresch, os produtos globais da alteração das rochas nas fases úmidas iriam ampliar a capacidade erosiva, através de agressivos processos de pedimentação, durante a fase de transição climática e em que se fez a quebra do equilíbrio biogênico e pedológico.
A documentação sedimentológica e geomorfológica que atualmente possuímos a respeito dos planaltos intertropicais brasileiros, constitui forte argumento favorável à hipótese de trabalho de Jean Dresch. Ainda, recentemente, para explicar a enorme quantidade de argilas cauliníticas existentes no meio dos sedimentos da Bacia de Curitiba, que provalvemente foi gerada em condições morfoclimáticas semi-áridas, Bigarella e Ab'Sáber foram de opinião que aquela pequena bacia tectônica foi criada numa fase de transição de climas úmidos para climas secos. De outra forma não se poderia explicar a presença de massas tão grandes de argilas cauliníticas. E, por outro lado, não fora a interferência de pequena falhas geomorfologicamente contrárias, ali teria havido apenas pediplanação (não acompanhada da formação de bacias detríticas), na fase principal da crise erosiva, como de resto parece ter acontecido em toda a rede das depressões periféricas do interior do Planalto Brasileiro. Desta forma, pode-se afiançar que as fases de aceleração dos fenômenos de plainação lateral (pedimentação e pediplanação) coincidem com os períodos de transição dos climas úmidos para os climas secos, em que logo de ínicio se processam modificações violentas nos quadros da vegetação florestal tropical, com ravinamentos ativos e forte descarnamento generalizado dos solos das vertentes mais vigorosas.Sobretudo quando tais modalidades de transições climáticas não coincidem com épocas de formação de falhas morfologicamente contrárias (atingindo apenas o estágio das drenagens exorreicas intermitentes, do tipo nordestiniano atual), os processos de plainações laterais extensivos permanecem em equilíbrio com os processos de evacuação dos detritos médios e finos até as áreas de plataformas ou de golfos epicontinentais, relativamente distantes.

Nas áreas intertropicais, as transições climáticas dos períodos secos para os períodos úmidos possibilitam de imediato um aumento da capacidade de transporte dos rios, assim como uma gradual conquista da perenidade da correnteza, com reinício da erosão de talvegue em inúmeros setores anteriormente dotados de canais anastomosados. Desta forma os rios passam a transportar e fazer rolar (rolamento, arrastamento e saltação) uma massa ponderável de fragmentos retirados de serras desnudas ou de vertentes até então dotadas de chão pedregoso, executando rápidas incisões em alguns setores do perfil longitudinal herdado das fases anteriores. 
É bastante lógico que o clima em umidificação inicial (forçando o estabelecimento de drenagens perenes e determinando uma lavagem mais pronunciada dos calhaus de vertentes) implique um enriquecimento das caixas aluviais, em matéria de fragmentos e detritos. E, nesse instante crítico, de aceleração e perenização das correntezas, pode-se obter o máximo da capacidade de entalhamento vertical dos cursos d'água nas regiões intertropicais, Note-se que essa retomada agressiva da erosão de talvegue tem o seu limite temporal balizado pela maturação dos solos e expansão dos revestimentos florestais, que gradualmente retêm o poderio ativo da erosão fluvial, peculiar à fase de transição climática.

Já, porém, com relação às fases de transição do úmido para o seco, os fatos devem ter atuado em sentido inteiramente contrário, pois o encorpamento generalizado dos mantos de decomposição, com redução de grandes massas de rochas a partículas finas (por argilização), deixa um saldo geral de solos que poderá participar, de modo muito ativo, no momento em que os mantos de vegetação florestal principiarem a fenecer devido a modificações climáticas bruscas e radicais. Tais fatos são particularmente sensíveis em áreas compartimentadas possuidoras de afloramentos extensivos de rochas cristalinas, muito sensíveis à decomposição química. Nessas conjunturas processa-se um roteiro dinâmico, morfoclimaticamente bastante agressivo, que pode culminar por verdadeiras fases de pediplanação regional. Agora, enquanto os rios gradualmente perdem sua perenidade (tornando-se, porém, mais torrenciais e adquirindo trechos anastomosados), as florestas se retraem para áreas-refúgio (refúgios climáticos do tipo dos brejos nordestinos, como bem o percebeu Pierre BIROT, 1957), acelerando-se a dessoalagem e o ravinamento múltiplo das vertentes e interflúvios, com desfiguração areolar das paisagens mamelonizadas anteriores.

A conseqüência global de tais modificações, realizadas em um tempo geologicamente rápido (no mínimo dois a três mil anos, em cálculo grosseiro), pode implicar o início ou reinício de processos de pedimentação. Assim, tudo leva a crer que, cessado o entalhamento vertical lento, que correspondia às fases úmidas estáveis e de grande equilíbrio morfoclimático, pedogênico e clímatobotânico, sobrevêm modificações generalizadas, que progridem agressivamente, sobretudo quando a vegetação fenece, regredindo para áreas limitadas e deixando os solos expostos aos novos processos morfoclimáticos. É daí por diante que as correntezas torrenciais passam a ser impotentes para evacuar as grandes cargas detríticas que recebem. E muitos outros fatos sobrevêm, quase ao mesmo tempo: as planícies meândricas tendem para planícies com canais anastomosados (braided channels); o calibre dos detritos arrastados em lençóis ou transportados nos intervalos torrenciais aumenta progressivamente, passando de siltes e argilas para areias, fragmentos e blocos, em grandes massas; aos poucos, as ações fluviais se combinam com fenômenos de plainação lateral, até certo ponto independentes da chamada erosão de talvegue. E, quando se chega a este esquema de trabalho, as rampas ascendentes laterais que independem do controle da erosão de talvegue vão comportar um recuo lateral particularmente ativo, devido aos materiais oriundos do desmantelamento generalizado da antiga estrutura superficial geopedológica da região, conforme suspeitou DRESCH (1963).

No decorrer do Terciário, ao que parece, todas as áreas correspondentes às atuais depressões periféricas brasileiras sofreram as conseqüências dessa dupla série de processos erosivos. Daí a possibilidade de formação daquelas depressões interplanálticas aplainadas de centenas de quilômetros de largura e de algumas dezenas de milhares de quilômetros de extensão. Tal ampliação dos quadros de aplainamento certamente não foi realizada por processos dotados de agressividade denudacional, permanente ou muito demorada, pois, entre as rápidas fases de erosão mais ativa (linear ou lateral), devem ter existido prolongados períodos de estabilidade relativa e de equilíbrio bioclimático e pedológico. Em outras palavras, no interior dos atuais compartimentos deprimidos do Planalto Brasileiro, segundo tudo leva a acreditar, alternaram-se, no decorrer do Terciário, processos morfoclimáticos de degradação lenta e fraca, com processos erosivos particularmente agressivos e dotados de grande capacidade de remodelação de quadros de paisagem. E, se é que nas regiões mais elevadas as ações mais fortes da erosão se fizeram sentir durante as fases de transição de climas secos para climas mais úmidos, nas depressões periféricas dotadas de fraca amplitude de relevo e algumas delas com seus níveis principais grosso modo tangentes aos níveis de base gerais ou regionais, a ação remodeladora foi particularmente sensível nas transições de climas úmidos para climas secos. 
Consideramos, aliás, tais fatos essenciais para a compreensão da evolução do relevo nas regiões intertropicais, que não comportaram estágios propriamente desérticos. Não se poderia conceber a modificação paisagística de um compartimento de relevo interplanáltico, com feições mamelonares para um quadro de pediplanos regionais, sem que se pudesse seriar os fatos aproximadamente dentro desse esquema.

Digno de nota, ainda, é o fato de que no interior das depressões periféricas, dotadas de uma certa largura - herdada de fases erosivas anteriores -, há sempre um reinício de atividades pediplanadoras, durante as transições dos climas mais úmidos para os climas semi-áridos moderados, comportando uma espécie de afeiçoamento e alargamento dos níveis anteriormente elaborados. Cuestas, ladeiras de chapadas ou bordos de erosão de maciços antigos passam a ser atacados pela pedimentação, adquirindo uma modalidade de recuo mais homogêneo, com eliminação parcial das irregularidades frontais das áreas anteriormente muito festonadas.

Se houver epirogênese positiva, concomitante a essas fases de retomadas de pedimentação ou de pediplanação, podem ser criados alguns pedimentos, ou mesmo pediplanos embutidos, fato sugerido pela observação de algumas áreas-chave no Brasil (depressão periférica gaúcha, depressão periférica paulista, depressões intermontanas e interplanálticas do Nordeste, em Pernambuco, na Bahia e no Rio Grande do Norte). Aliás, tais efeitos também são produzidos pelas variações de nível base, de controle glácio-eustático, fato que pode ser observado em pequenos quadros esquemáticos em inúmeras áreas sublitorâneas da fachada atlântica tropical e subtropical úmida do país. Nesse sentido, os estudos realizados por BIGARELLA, MARQUES FILHO \& AB'SABER (1961), na região de Garuva (Santa Catarina), constituíram um ponto de partida novo para o entendimento das retomadas de pedimentação quaternárias das regiões tropicais úmidas. Fatos idênticos foram por nós verificados na zona sublitorânea do Sul de Santa Catarina, na porção oriental da depressão periférica gaúcha, e na depressão central do domo de Itabaiana. $\mathrm{Na}$ região serrana do Espírito Santo, Manuel Correia de ANDRADE (1959) constatou a presença de um pedimento rochoso na base de um domo-de-esfoliação. Mais tarde, em julho de 1961, na companhia dos professores João José Bigarella e Riad Salamuni, pudemos distinguir, em área próxima, no Nordeste de Minas Gerais, um verdadeiro campo de pedimentos embutidos, de diferentes idades. Identicamente, na boutonnière de Lages, em Santa Catarina, constatamos bons exemplos de pedimentos embutidos, gerados em climas subtropicais de planalto.

Por último, queremos nos referir à presença de áreas tectônicas como zonas ou faixas preferenciais para a formação de depressões intermontanas aplainadas, no interior de nosso país. $\mathrm{Na}$ realidade, enquanto os pediplanos tiveram maiores possibilidades de se estender no interior das depressões periféricas subseqüentes, os pedimentos caminhavam sobretudo nas faixas de litologias menos resistentes e nas faixas sujeitas a diaclasamentos muito densos, em zonas de tipo intermontano. No pediplano intermontano do Moxotó, como no desvão existente ao sul das serras capeadas por depósitos da Série Serra do Martins, no Rio Grande do Norte, existem exemplos particularmente expressivos de tais fatos. A própria bacia do Baixo Ribeira, na zona sublitorânea sul de São Paulo, constitui um caso significativo de uma penetração em forma de embayement da pediplanação, por entre os longos festões apalachianos das serras regionais.

O estudo da macrocompartimentação topográfica do Planalto Brasileiro incide diretamente sobre o tema das depressões periféricas. Esse, aliás, o escopo do trabalho que realizamos. Entrementes, se tivéssemos que selecionar um campo de estudos particularmente rico em problemas de compartimentação topográfica de detalhe, penderíamos francamente para a pesquisa em torno dos compartimentos alveolares das regiões serranas do Brasil de Sudeste. Desde nossas primeiras pequisas em tais áreas de planícies alveolares - expressão introduzida entre nós por Francis Ruellan - pudemos perceber a grande importância geomorfológica de tais depressões aluviais, embutidas entre morros, situadas em pontos de concentração de drenagens ou a montante de soleiras rochosas resistentes.

Estudando alveólos de diferentes ordens de grandeza, pudemos chegar à conclusão inicial de que eles possuem também diferentes ordens de antigüidade, dentro dos quadros do Quaternário e que, via de regra, a idade pode ser avaliada pelo estudo dos níveis de erosão mais elevados (pedimentos, terraços), que neles estão embutidos. Assim, pudemos constatar que a idade dos compartimentos alveolares é tanto 
maior quanto mais amplo e bem compartimentado seja o seu esquema de relevo. Na prática, isto significa dizer que ele é tão antigo quanto a idade do mais elevado nível de erosão nele existente.

Pelo exame de fotografias aéreas, pudemos estudar os aspectos morfológicos globais de alguns alvéolos de dimensões reduzidas (de algumas centenas de metros quadrados até um ou dois quilômetros quadrados de área). Tais observações nos possibilitam inferir que a maior parte dos pequenos compartimentos alveolares depende da existência local de diáclases tectônicas entrecruzadas ou de soleiras rochosas localizadas a jusante, que obrigam a concentração de drenagem à sua retaguarda. Ambas estas causas possibilitam a abertura de planícies ou compartimentos alveolares, em fases especiais do entalhamento dos diferentes setores dos rios provenientes das regiões serranas.

A ampliação dos alvéolos tanto pode ser feita por pedimentação embrionária, como por terraceamentos sucessivos ou, ainda, simplesmente, por uma transição rápida entre a erosão de talvegue, atrás de níveis de base locais, com posterior aluviação, meandração e plainação flúvio-aluvial restrita. Inúmeros são os casos de antigos pedimentos ou altos terraços, pertencentes a grandes compartimentos alveolares, que foram posteriormente mamelonizados e retrabalhados pela formação de baixos terraços e planícies aluviais, muito recentes. Pode-se ter como certo que os grandes compartimentos alveolares (bacia do Alto Jundiaí, sítio de Juiz de Fora) têm uma história geomorfológica complexa, incluindo pedimentação nas fases secas e retrabalhamentos fluviais e morfopedológicos nas fases úmidas.

Será sempre cabível a objeção de que não é possível avaliar a exata extensão dos processos erosivos, correspondentes às fases de climas agressivos. Entrementes, é perfeitamente possível acompanhar parte do roteiro de tais processos, observando-se áreas sujeitas a fortes desequilíbrios por ações antrópicas. Queremos crer nesse sentido que não existe nada melhor no cinturão intertropical do Globo - como laboratório ocasional para a geomorfologia dinâmica das regiões intertropicais - do que as áreas de mares de morros e escarpas marginais do Brasil tropical atlântico. Um dos melhores exemplos, nesse sentido, é o das áreas mamelonares do médio Vale do Paraíba, no Estado do Rio de Janeiro, que foram trabalhadas predativamente pelo homem, desde os primórdios da instalação das culturas cafeeiras na região (1780-1790). Ali, em pouco mais de um século e meio de maus-tratos sucessivos, que perturbaram o equilíbrio de uma paisagem ecológica natural típica do domínio dos mares de morros florestados, processou-se um pouco daquilo que poderíamos chamar de efeitos globais de uma fase inicial de ação de um clima de tipo agressivo (dessoalagem, ravinamentos múltiplos, fenecimento da vegetação florestal anteriormente existente, modificações irreversíveis nas aptidões dos antigos solos florestais, e, conseqüentemente, uma impossibilidade ecológica para a reexpansão natural das matas). E tudo isso sem que a erosão torrencial tenha atingido, ainda que de leve, o que seria de se esperar numa transição climática típica. Tratou-se apenas de uma crise morfológica de tipo agudo, cujas lesões foram parcialmente cicatrizadas (caso das bossorocas senis), mesmo porque o clima geral continua a ter os mesmos elementos e o mesmo ritmo, a drenagem regional ainda funciona como drenagem perene, as planícies de inundação ainda são tipicamente meândricas. Evidentemente, se a modificação dos processos dependesse de fatos $\mathrm{cli}$ máticos, e não de fatores antrópicos, a atividade remodeladora realizada pela acentuação dos processos de ravinamento e descarnamento dos solos teria um aspecto marcadamente areolar, através de uma espécie de crise morfogênica crônica, ininterrupta e irreversível.

Fatos análogos e de ação muito mais rápida podem ser encontrados nas áreas de relevo muito enérgico localizadas nas encostas da Serra do Mar, no Estado do Rio de Janeiro. Ao longo da Rodovia BR-2, entre São Paulo e Paraná, nos setores mais acidentados, pertencentes às encostas festonadas da Serra do Mar, existe campo para oportunos estudos sobre a aceleração dos processos provocados por rápidos desequilíbrios na paisagem natural, em áreas de escarpas florestadas de regiões tropicais úmidas. Em qualquer desses casos, porém, há que buscar informações, lembrando-se de que elas, mercê dos fatores limitantes, só têm validade para nos dar uma pálida idéia do que realmente aconteceria durante uma fase de intervenção de climas agressivos. De resto, os conhecimentos obtidos muito interessam para a geomorfologia aplicada, já que o projeto de construção de tal estrada primou por um completo desconhecimento da estrutura superficial das paisagens e por uma criminosa despreocupação em relação à imedia- 
ta revanche da natureza tropical sobre as construções humanas. Daí o drama atual, de ordem técnica e financeira, que o Governo enfrenta para a conservação dos cortes e aterros da importante e mal construída rodovia.

A observação de tais casos de crises morfogênicas agudas nos fornece uma boa proposição para o entendimento das bases da formação de uma bacia sedimentar de compartimento de planalto em regiões intertropicais. Tendo-se em vista a própria estrutura superficial das paisagens da área de mares de morros do Brasil de Sudeste, pode-se afiançar que tais extensões de topografia mamelonar são praticamente constituídas por massas de rochas reduzidas a partículas finas, massas essas que vão desde espessuras que variam entre 8 e 10 metros (em granitos) até 60 80 metros (em certos gnaisses). Desta forma, trata-se de morros dominantemente de terra e não de rochas, em extensos setores regionais, fato que se pode depreender logo pela observação da base central dos grandes cortes, feitos ao longo das modernas rodovias do Brasil de Sudeste. Ora, imagine-se uma fase de clima agressivo agindo sobre solos e regolitos, tão profundos e universais, nessas áreas de relevos mamelonares extensivos. Se a modificação climática ultrapassasse 0 estágio dos climas de savana, atingindo o caráter de climas secos (de tipo nordestiniano por exemplo), após o fenecimento da vegetação florestal sobreviria uma forte ação de dessoalagem, descarnamentos de manto e ravinamentos múltiplos, que, em conjunto, determinariam a remoção de enormes massas de argilas, areias, gravas e fragmentos. Tais saldos detríticos maciços poderiam ser evacuados ou não, dependendo da capacidade evacuadora da drenagem que presidiu à modificação climática e da existência ou não de perturbações tectônicas contemporâneas aos processos. Evidentemente, o ritmo da sedimentação, em casos de bacias tectônicas, dependeria sempre da velocidade dos afundamentos e do próprio ritmo e duração dos climas degradados responsáveis pelas ações morfogênicas em torno das áreas de retenção de sedimentos continentaias. Essa conjugação eventual de episódios tectônicos com mudanças climáticas (sobretudo no caso de mudanças diretas de climas úmidos para climas secos) nos parece essencial para a explicação das bacias de compartimentos tectônicos do Brasil de Sudeste (bacias de São Paulo, Taubaté e Curitiba) assim como, com algumas modificações ponderáveis no estilo da tectônica, para a explicação dos depósitos pertencentes ao Grupo Barreiras. Em relação a esse último caso, aliás, há que pressupor sempre que as argilas, as gravas e os fragmentos tenham sido removidos, proparte, de compartimentos interplanálticos, sujeitos a alguma decomposição mais profunda de rochas, e dotados de uma certa mamelonização de formas topográficas.

Evidentemente, escapou aos objetivos do presente trabalho o estudo geográfico regional das diversas áreas de depressões periféricas brasileiras. Do mesmo modo - ainda que seja uma das maiores preocupações do autor - não houve oportunidade para um tratamento mais específico do tema das depressões periféricas, com vista ao planejamento econômico regional da hinterlândia brasileira. Nesse sentido, estamos certos de que cada uma das regiões de depressões periféricas brasileiras - quer pela sua situação nos quadros regionais maiores de que participam, quer pelo seu esquema de solos e aptidões agrárias, ou pelas condições geoeconômicas de sua rede de cidades ou das redes de cidades de que faz parteconstitui uma área particular a ser estudada por uma equipe de planejamento, eclética e bem informada. É fora de dúvida que, nesse trabalho todo, deverá caber uma grande parcela de responsabilidade aos estudos dos geógrafos, já que suas avaliações sintéticas são básicas para a elaboração de planos regionais. Mas, também, é igualmente certo que nada de bom e realmente científico se fará sem a colaboração dos pedólogos, hidrólogos, agrônomos e geomorfologistas especializados em estudos da estrutura superficial das paisagens.

Localizadas à retaguarda dos principais maciços antigos que respondem pela existência da elevada fachada atlântica de nosso país, as depressões periféricas brasileiras foram as primeiras grandes vias naturais de circulação para a penetração interior e para as ligações inter-regionais, de longa distância, entre os primeiros núcleos altamente isolados entre si, da colonização portuguesa no Brasil. Geógrafos e historiadores, em mais de uma oportunidade, salientaram o papel da depressão periférica paulista na história do desenvolvimento dos caminhos antigos para o Sul e Centro do país. Comparando-se o roteiro dos caminhos interiores, mais clássicos, do Nordeste, do Leste e do Extremo-Sul do Brasil, em cotejo direto com o mapa geomorfológico do país, pode-se apreender o quanto de importância tiveram as áreas de depressões interplanálticas para a elaboração da primeira rede de circulação interna em quase toda a metade oriental do Brasil. 
Acreditamos que apenas o tratamento de dois temas geográficos relativos às depressões periféricas brasileiras - ou seja, redes de circulação e redes de cidades - daria para alimentar muitos anos de estudos e pesquisas. Do Nordeste ao Rio Grande do Sul, e de São Paulo a Goiás e Mato Grosso, tais temas apresentam uma grande diversificação de aspectos regionais, guardando interesse para os mais variados ramos da Geografia do Brasil, já que incluem aspectos básicos da geografia das populações e dos gêneros de vida, alcançando, depois, setores mais complexos, pertencentes à geografia urbana, à geografia agrária e industrial, assim como até à geografia das fronteiras.

No que tange especificamente ao estudo das redes de cidades do interior do país, o tema das depressões periféricas nos apresenta aspectos dos mais interessantes e instrutivos. Em São Paulo há toda uma rede de cidades da depressão periférica paulista (e, subsidiariamente, uma rede de cidades da fall line paulista), sujeita a incipientes processos de industrialização. No Rio Grande do Sul existem duas redes de cidades ao longo de uma mesma faixa de depressões periféricas: as cidades do setor centro-oriental da depressão periférica gaúcha (tradicionalmente chamada depressão central) e as cidades do setor sudoeste da mesma depressão, as quais participam de um esquema de rede urbana mais extenso, o qual engloba as cidades da Campanha e da Fronteira (porção sudoeste interior, cuesta do Caverá e Fronteira de Sudoeste). No extremo sul-ocidental do Rio Grande, a rede de cidades, típica da depressão, extravasa os quadros rígidos dos compartimentos topográficos interiores, para atingir o vale do Uruguai e as áreas de fronteira, pertencentes a uma mesma área geográfica e geoeconômica.

No Nordeste brasileiro, da mesma forma que os pediplanos extravasam para além dos limites rígidos das depressões periféricas, a rede de cidades sertanejas - num mesmo esquema histórico, cultural, geoeconômico e arquitetônico - extravasa de todos os limites, abrangendo praticamente a extensão inteira do domínio dos sertões semi-áridos, da Bahia ao Piauí. Trata-se da grande rede de pequenas cidades do Sertão, na acepção que esta palavra possui no domínio das caatingas. Já no vale do São Francisco, ou seja, ao longo da depressão periférica subseqüente são-franciscana, é mais o rio, propriamente, que dá unidade à rede de cidades da região, fato muito fácil de ser entendido.
Em Goiás e no Centro-Oeste, as complexas depressões periféricas e depressões monoclinais regionais possuem apenas ilhotas de humanidade, quase que completamente desligadas de verdadeiras redes regionais de cidades de depressões periféricas. Aí, talvez, mais do que em qualquer outra parte do país, as cidades localizadas em depressões periféricas são apenas pontos ocasionais de concentração humana, ligadas a etapas de velhos caminhos de penetração ou ligação e à frouxa rede de urbanização arcaica não amarrada a compartimentos topográficos. As vias de circulação modernas, ao invés de modificar tais quadros, apenas contribuíram para definir melhor as funções de tais pontos de concentração urbana, não integrados em esquemas de base fisiográfica.

No Paraná e Santa Catarina, as cidades situadas em depressões periféricas ou depressões monoclinais, raramente chegam a formar redes similares àquelas que se conhecem em São Paulo e no Rio Grande do Sul. Aliás, as grandes rodovias interestaduais de ligação, recentemente construídas no Sul do Brasil, vieram perturbar os velhos esquemas de redes de cidades de depressão (periféricas ou monoclinais), as quais, desde o começo do século, haviam se esboçado tenuamente por entre os patamares de planaltos regionais. Entretanto, aí, muito mais do que se pode esperar para com Mato Grosso e Goiás, poderão vir a se definir algumas redes de cidades de depressão.

Existem algumas tendências passíveis de serem discriminadas, com relação à questão de formação de redes de cidades em depressões periféricas nos planaltos do Sul e do Centro do país. Ao que parece, onde os planaltos muito têm a ver com as áreas de maior desenvolvimento econômico-regional, as cidades de depressão tendem a perder o caráter de redes compartimentadas, vindo a se tornar centros secundários isolados, que ficam gravitando em torno das capitais regionais, situadas em planaltos férteis ou de alguma forma mais bem desenvolvidos (Norte do Paraná, região de Campo Grande-Dourados, Ponta Grossa, Triângulo Mineiro, Lajes e, mais recentemente, a região de Brasília).

Pode-se afiançar, por outro lado, que a tendência, em relação aos setores mais interiores e menos desenvolvidos das depressões periféricas brasileiras, é para ratificar tais modalidades de integração de redes, com franco prejuízo para o 
desdobramento das redes de cidades típicas de depressão. Desta forma, antes mesmo de se formarem novas redes urbanas em compartimentos fisiográficos definidos, houve uma espécie de amarração de algumas aglomerações urbanas pertencentes a áreas mal povoadas e subdesenvolvidas - aos quadros de um novo esquema de super-rodovias, pertencentes a um Brasil que se amplia e se moderniza dentro de suas próprias fronteiras. Quer nos parecer, entrementes, que passada a era das ligações de escala subcontinental (Belém-Brasília; Belém-Acre; Rio-Bahia; São Paulo-Rio Grande), talvez se torne imprescindível uma melhoria progressiva das redes de circulação subsidiárias, com reais benefícios para as cidades localizadas em depressões periféricas interiorizadas, numa espécie de integração efetiva, de trama areolar. Tal fato será particularmente útil para o desenvolvimento da hinterlândia na medida em que planaltos e depressões possuam aptidões geoeconômicas diferenciadas e complementares.

Daí, sentimo-nos no dever de alertar a quantos perseguem a temática do planejamento regional integrado sobre a grande importância intrínseca dos conhecimentos geográficos globais e regionais a respeito dos compartimentos interiores do Planalto Brasileiro. Isso para não falar na própria importância que tais noções sobre a compartimentação topográfica interior possuem do ponto de vista intercientífico, ou seja, no que diz respeito às informações básicas para os climatologistas, hidrólogos, agrônomos e fitogeógrafos.

Tudo indica que não mais será possível realizar esquemas de planejamento regional, baseados em fatos fisiográficos isolados (hidrografia, topografia, solos). Pouco valem, como pano de fundo do planejamento, as redes hidrográficas que ligam o nada ao quase nada. Por outro lado, traçar estradas de longo curso, através dos cha- padões interiores, sem atender às necessidades presentes das áreas de produção, situadas à margem de tais planaltos divisores, é igualmente contestável. No fundo, tal solução é o reverso da medalha de uma solução que também não era inteiramente certa; ou seja, aquela que, no passado, redundou num aproveitamento sistemático de algumas depressões periféricas para o traçado de grandes rotas. Pode-se dizer que, na história das obras isoladas que fizeram parte dos velhos planos fragmentários do Governo Brasileiro, houve avanços e recuos tateantes, nesta ou naquela direção, favorecendo algumas áreas em detrimento de muitas outras. Na realidade, porém, alguns dos planos regionais elaborados nos últimos vinte anos, entre nós, não foram superiores às medidas de interesse regional, levadas a efeito nos fins do século passado e na primeira metade do atual, porque também não atenderam a um desenvolvimento harmônico do território nacional.

Na estratégia da modernização da hinterlândia, há que haver tais avanços e recuos, a fim de assegurar a sorte geoeconômica das mais diversas áreas de um país que possui a escala de um continente. Pensamos, entretanto, que a melhor política de planejamento regional, aplicável ao país, no presente momento, seria aquela que levasse em conta as peculiaridades regionais dos principais domínios fitogeográficos, morfoclimáticos e geopedológicos, associada a um bom conhecimento da rede de compartimentos interiores, que participa do grande mosaico fisiográfico inter e extratropical do território brasileiro. Mesmo porque, em relação ao setor dos estudos básicos, seria completamente absurda qualquer tentativa de planejamento regional - cientificamente válida - sem que os responsáveis por tais estudos tivessem noções sobre tais fatos geográficos de infra-estrutura fisiográfica.

\section{REFERÊNCIAS BIBLIOGRÁFICAS}

AB'SÁBER, A.N. 1949. Regiões de circundesnudação pós-cretácea, no Planalto Brasileiro. São Paulo: Boletim Paulista de Geografia, 1: 3-21.

1951. Sucessão de quadros paleogeográficos no Brasil do Triássico ao Quaternário. São Paulo: Anuário da Faculdade de Filosofia "Sedes Sapientiae"
(Universidade Católica de São Paulo), 1950-51, p. 61-69.

AB'SÁBER, A.N. 1964. O relevo brasileiro e seus problemas. In: AZEVEDO, A. (Ed.) Brasil, a terra e o homem, vol. 1, p. 2135250. São Paulo: Companhia Editora Nacional.

ANDRADE, M.C. 1958. O relevo da zona pio- 
neira do Espírito Santo e da região Contestada. Recife: Editora do Diretório Acadêmico da Faculdade de Filosofia de Pernambuco da Universidade do Recife.

ANDRADE, M.C. 1959. Os rios do açúcar no Nordeste Oriental - IV. Os rios Coruripe, Jiquiá e São Miguel. Recife: Publicações do Instituto Joaquim Nabuco de Pesquisas Sociais.

BIGARELIA, J.J.; MARQUES FILHO, P.L. \& AB'SÁBER, A. N. 1961. Ocorrência de pedimentos remanescentes nas fraldas da serra do Iquererim (Garuva, SC). Curitiba: Boletim Paranaense de Geografia, 4/5: 7181.

BIGARELIA, J.J.; SALAMUNI, R. \& AB'SÁBER, A. N. 1961. Origem e ambiente de deposição da Bacia de Curitiba. Curitiba: Boletim Paranaense de Geografia, 4/5: 71-81.

BIROT, P. 1957. Morphologie de la région de Recife. Paris: Bull. de l'Assoc.des Geografes Français, n. 263-264.

1959. Géographes Physique Générale de la zone intertropicale (a l'exclusion des deserts), Paris:C.D.U.

CAILLEUX, A. \& TRICART, J. 1956. La era Quaternaria. Problemas y metodos de estudo. Cons. Sup. de Invests. Cients. Barcelona.
DRESCH, J. 1963. Geomorfologia dos escudos intertropicais. São Paulo: Conferência na Faculdade de Filosofia, Ciências e Letras da USP (agosto de 1963).

KEGEL, W. 1956. As incorformidades na bacia do Parnaíba e zonas adjacentes. Rio de Janeiro: Boletim da Divisão de Geologia e Mineralogia do Departamento Nacional da Produção Mineral, n.160.

MAACK, R. 1956. Os propósitos da Geografia Moderna e a situação atual do ensino e das pesquisas geográficas no Paraná. Arquivos de Biologia e Tecnologia, vol. XI, p. 163-195.

PAIVA, G. Geologia do município de Lages, Santa Catarina. Rio de Janeiro: Boletim do Serviço Geológico e Mineralógico do Brasil, n. 69

PENCK, A. 1928 Neuere Geographie. Sonderhand der Zeitsch. d. Ges. fur Erdkunde zu Berlin, p. 31-56 Berlin.

TAKEDA, F. 1958. Esboço geológico de Santa Catarina. In: Atlas Geográfico Santa Catarina, p. 26-29. Dir. Reg. de Santa Catarina, CNG (IBGE). Florianópolis.

WALTHER, K. 1924. Etudios geomorfologicos y geologicos - Base de la Geografia física del país. Rev. del Inst. Hist. y Geogr., tomo III, n. I, Imp. " El Siglo Ilustrado", Risso \& Ayala, Montevidéo.

\section{Endereço do autor:}

Aziz Nacib Ab' Sáber - Instituto de Estudos Avançados - USP, Edifício da Antiga Reitoria, Av. Prof. Luciano Gualberto, Travessa J, 374, Térreo, Cidade Universitária, 05508-900, São Paulo, SP, Brasil. 